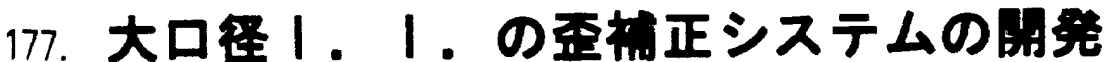

\section{Development of Distortion Correcting System for Large Field I.I.}

（株）島津製作所 医用機器工場
○畐田 義則 ・ 小山 博

(Yoshinori Tomida) (Hiroshi Koyama)

【目的】X線イメージインテンシファイア（ＩＩＩ）は，入力面が凸の球面状に唀曲していることから，同じ 長さの被写体であっても視野の中心から外れるほど出力面に大きく現れる系巻き状の歪みをもつ。また地磁気の ような磁場の影響で I．Ｉ．の電子軌道が歪められてS字状の歪みを生じる。特に14インチ I . I .や16インチ I．I．のように入射面視野寸法の大きい大口径 I . I . ほどこれらの歪は影著になる。我々はこれらの構造上生じ る歪みを低減し良質な画像を提供する。

【方法】糸卷き歪みを低减するために歪補正機能を備えた光学系を開発した。 歪補正は光学系 1 次レンズ側（Ｉ．Ｉ．側）で行い，各視野での歪を考慮して全体の補正量を算出した。

また S字歪みを低減するため，前面から入射する地磁気による影敏を抑える磁気シールドを開発した。磁気シ 一ルドは入射面を覆うため，その材質・厚みにとくに注意を払った。また入射する磁場を効率よく外部へ導くた めにその側面部についても効果的な形状になるように設計した。

【結果】図1および図2に16インチ I．Ｉ．に対し等間隔のメッシュをS I D： $1 \mathrm{~m}$ で撮影したときの解析図 を示す。光学補正により，中心部に対する周辺部の抁大率を小さくすることができた。この補正により16イン チ視野 $90 \%$ 位置の微分歪は従来の䄪 $50 \%$ 改善することができた。

図3および図4に16インチ I．I．に対し等間隔のメッシュをS I D：1 mで撮影したときの出力像を示す。 図 3は地磁気の影警が大きい南北方向にＩ．Ｉ．を向けたときに相当する地磁気をＩ．Ｉ．に与えたときに得られる 出力像である。磁場の影響でねじれた像は，磁気シールドの装着によって外部磁場の影留が低減され，ほぼ無視 できる程度までなくすことができた。このことは透視台の起倒やCアームの回転等によって I．Ｉ．の向きが変わっ ても画像の移動が少ないため，例えば回転D S A のように頻繁に I．Ｉ．の向きを変える術式に非常に有用である。 【まとめ】光学補正と前面磁気シールドの開発で系巻き歪み及びS字歪みを低減した良質な画像を提供できた (図 4)。またこの補正法は，光学系の交换と磁気シールドの取り付けですむため，既設のX線撒影装置にも簡便 にかつ安価に対応できる。

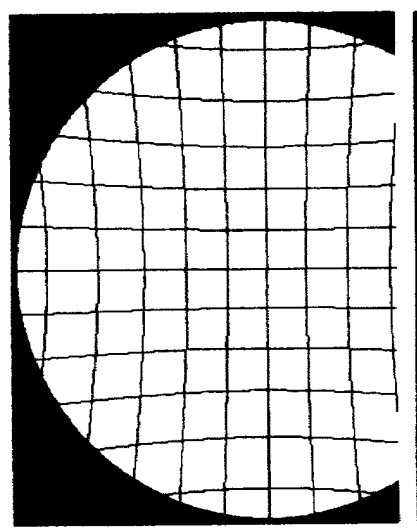

眓1. 光学榑正なし

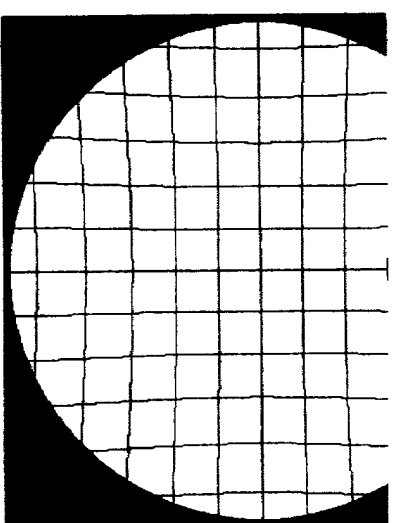

图2. 光学補正あり

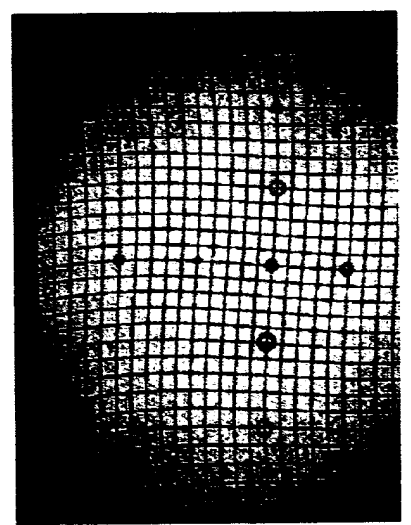

図3. シールドなし

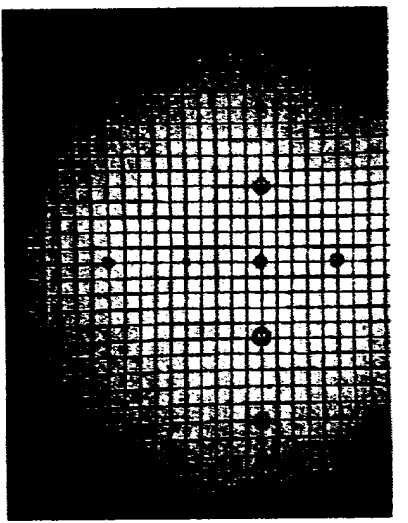

図4. シールドあり 